\title{
POINT OF VIEW \\ AND THE MODALITIES OF NARRATIVE
}

Keywords: narratology, modality, multimodal logic, point of view, Bulgarian Guillaumist School

Słowa kluczowe: narratologia, modalność, logika wielomodalna, punkt widzenia, bułgarska Szkoła Guillaumistów

\section{Narrative potentiality}

The present paper is a part of a larger research project aimed at reconsidering the problem of literary potentiality by means of a literary model theory. Currently, the number of issues that literary scholars would agree upon is rather small, but one of them is the concept that there can be more than one reading, more than one interpretation of a literary work of art. This seemingly simple idea nevertheless poses a difficult problem before the scholar, for how are we to know if what we ascribe to the work is not simply our own interpretation? In order to answer such a question one has to face the problem of literary potentiality, i.e. the possibility that is inherent to the literary work which makes different readings possible. The risk of reducing this possibility to general (and for the most part vague) notions such as the reader's cultural background, the historical period, or general linguistic characteristics, thus shifting the possibility to important yet exterior factors, lies in the implication that if factors exterior to the work are the only aspect that matters, then the work itself would not matter, i.e. it would be of no importance, for even a devoted scholar will, after all, be speaking only about him or herself, about the cultural, historical, and linguistic aspects, and not about that given work. This is, of course, a simplified manner of presenting the problem, yet it makes it clear why the idea that there is a unique potentiality to works has to be taken into account and should not be discounted lightly. Since one cannot have direct access, as it were, to literary potentiality, it seems reasonable to build a model of it that is reflexive of its own 
potentiality. Thus, methodologically a literary model theory is needed. In dealing with literary potentiality, such a theory, which is currently being developed, ${ }^{1}$ will have to account for the modelling activity of the works themselves and the manner in which the works indicate their own modalities. However, the more one pays attention to the characteristics of the literary works in the process of building a working model of them, the more one realises that it would be pertinent to speak of a knot of potentialities of different kinds, and not just one potentiality.

From this perspective the question regarding narrative modalities is of great significance. As open to non-previsible and non-predictable readings as the above-mentioned literary potentiality is, it is still paradoxically restricted in the case of narratives, for the coherence of a narrative does not allow the story to develop in just any direction. If the question whether the relevant directions for the development of a story is meaningful, then its meaning implies that some of the directions are forbidden or unlikely and, what is more, it implies that along its way the story exhausts its potentiality, as it were, so that there is a point after which it is difficult for the narrative to continue. A story can come to an end. It can bring us to a closure. And this very fact poses a serious problem. What was vaguely called the "relevant directions" of a story is related to questions of genre, verisimilitude, etc., but beyond these loom social conventions and cultural attitudes that define the modalities of the story. Therefore, one can speak of a specific narrative potentiality whose laws are determined by the incorporation of social conventions and cultural attitudes as narrative modalities in the work. These narrative modalities direct the logic of the story so that after certain moves are made, other possible moves turn out to be excluded and are no longer acceptable. ${ }^{2}$ Exhausting the narrative potentiality would mean the end of the story. ${ }^{3}$ Such an end may seem unlikely in the field of literature, where there is freedom to cross boundaries and invent the impossible. Still, even though it may be possible to invent ever new prolongings of a story (Hollywood sequels or TV shows offer telling examples), these would be unconvincing and often not accepted by the general public. Thus it could be stated that narrative potentiality is implied by the very idea of a narrative logic,

${ }^{1}$ See Darin Tenev, Fikcia i obraz. Modeli [Fiction and Image. Models] (Plovdiv: Zhanet 45, 2012); Robert Matthias Erdbeer, "Poetik der Modelle," Textpraxis. Digitales Journal für Philologie, no. 11 (2015).

${ }^{2}$ Here I will focus on narrative potentiality in the way it operates at the level of the story, and not at the level of discourse, or on the relationship between story and discourse, on the one hand, and between these two and narration on the other. In the final part of the paper I will very briefly turn to the relation between story and discourse.

${ }^{3}$ See Boyan Manchev, "Otvad tvorbata: metamorphozata na razkaza" ["Beyond the Work: the Metamorphosis of the Story"], in Boyan Manchev et al., Vremeto na metamorphozata. Opiti vurhu Kafka (Sofia: Iztok-Zapad, 2016), 137-152. 
"describing the complete network of options logically open to the narrator in any point of his narrative, in order to continue the story once it has begun." 4 The development of narrative logic in a concrete literary work leads to the "logical" end of the story and thus to the exhaustion of its potentiality. Even in the case when there is more than one ending (as in John Fowles' The French Lieutenant's Woman or, more recently, in Milorad Pavić's Unique Item, which is a book with a hundre endings ${ }^{5}$ ), the very idea of an end of the story implies that from that point on the story cannot be continued, and this would be valid for any of the multiple ends. The exhaustion of narrative potentiality thus suggests that after a certain point, continuation of the story becomes impossible; for instance, it is possible for Gregor Zamza to return in the form of a butterfly after his death in Kafka's Metamorphosis, or he may reappear as a zombie-cockroach, but these possibilities are not seen as part of the narrative potentiality of the particular work.

What I call 'narrative potentiality' is not to be conceived as a particular narrative modality. It is rather the mode of existence of all narrative modalities, e.g. if one takes into account the four most often discussed modalities after Greimas, i.e. ability (pouvoir), desire (vouloir), knowledge (savoir), and obligation (devoir), ${ }^{6}$ it should be stressed that narrative potentiality is not to be confused with ability or possibility (pouvoir), as it is not a modality among others (say, obligation, knowledge, desire), for it is what encompasses all four of these modalities. In order to understand the nature of narrative potentiality, however, one cannot but study the function of the modalities and their various associations.

In this paper I will address the question of the relationship between narrative modalities and point of view as one of the vantage points for the building of a model of narrative potentiality. In this I will employ the theoretical basis provided by the Bulgarian Guillaumist School, and particularly the theoretical heritage of Christo Todorov, whose work, while close to Greimasian semiotics, proposes a different conception of the role of modality in narrative texts.

${ }^{4}$ Claude Bremond, Logique du récit (Paris: Seuil, 1973), 8. Italics are mine - D. T. All translations, if not specified otherwise, are mine.

${ }^{5}$ John Fowles, The French Lieutenant's Woman (New York: Panther Books, 1969); Milorad Pavić, Unikat (Beograd: Bereta, 2004). Multiple endings pose particular problems that I cannot discuss here. Let it be simply stated that at least one of their functions is to disrupt the narrative potentiality, i.e. to disrupt the notion of a single narrative logic and to thus indicate the literary potentiality as open and non-predetermined; the more non-conclusive the endings, the more this openness becomes perceptible.

${ }^{6}$ See Algirdas Julien Greimas, "Pour une théorie de la modalité," Langage, no. 43 (1976): 90-107; Gerald Prince, Dictionary of Narratology (Lincoln and London: University of Nebraska Press, 1987); Algirdas Julien Greimas, Joseph Courtès, Semiotique. Dictionnaire raisonné de la théorie du langage (Paris: Hachette, 1993). 


\section{The multimodality of narrative logic}

One of the most startling aspects in the eyes of a logician regarding narrative modalities, whether these be thought in a Greimasian manner or otherwise, is the combination of several types of modality. Possibility, for example, is usually conceived as an alethic modality (together with necessity, contingence, and impossibility); obligation is a deontic modality, and so on. This issue was addressed by Greimas, who claims that even if their denominations make us distinguish them as different types, their syntactical definitions show that they share a common ground and should be studied together - the only crucial difference being between the modalisations of being and those of doing. ${ }^{7}$ The narrative analyses reveal not only that modalities from different types (alethic, volitive, deontic, epistemic) are connected, but that there are transitions from one modality to another within a story, e.g. the desire that should lead to the obtainment of knowledge and abilities in order to be fulfilled. This is not just a linguistic problem but also a problem for the logician who would need a theory that is different than that proposed by most contemporary modal logic research studies. To put it succinctly, narrative modalities reveal a multimodal logic. The logical investigations of multimodality are a task before a non-classical pluridimensional logic such as the one proposed by the Bulgarian philosopher Deyan Deyanov. ${ }^{8}$ Here I will focus only on the narrative functions of the interweaving of different modalities. According to Greimas and his school, there can be modalisations with regard to the statement of an act (doing) and with regard to the statement of a state (being). ${ }^{9}$ Thus four initial forms of modalisation are conceivable: the doing modalising the being (performance); the being modalising the doing (competence); the being modalising the being (veridictory modalities); and the doing modalising the doing (factitive modalities). In addition, the most widely used modalities of wanting (vouloir), having to do (devoir), being able (pouvoir), and knowing (savoir) can modalise both the being and the doing. ${ }^{10}$ The modal transitions, as transitions from one modality to another (e.g. a transition from the obligation to do something to the knowledge necessary to do it), lead to an act or a state. Combinations between the modalities are also possible, where the combined modalities can be complementary, conformed, incompatible, or contradictory. ${ }^{11}$ Even though Greimas does not discuss the issue, one can easily notice that in the case of incompatibility or contradiction

\footnotetext{
${ }^{7}$ Greimas, "Pour une théorie de la modalité," 98-99.

${ }^{8}$ See Deyan Deyanov, "Za granicite i mnogomernostta na logicheskoto" ["On the Limits and the Pluridimensionality of the Logical"], Sociologicheski problemi, no. 1-2 (2002), 196-203.

${ }^{9}$ See Greimas, Courtès, Semiotique, 230.

${ }^{10}$ Ibid., 231. See also Greimas, "Pour une théorie de la modalité," 96-97.

${ }^{11}$ Greimas, "Pour une théorie de la modalité," 101-106.
} 
(e.g. where there is an obligation to do something accompanied by the impossibility to do it, or with the desire not to do it) there is a narrative conflict.

The modal categories correspond in a sense to what Tzvetan Todorov called simple narrative transformations, ${ }^{12}$ where there is only one predicate which is modalised (e.g. the doing modalised as 'having to do' or 'able to do'). It should be noted that knowing is not a part of the simple narrative transformations; Todorov lists it in the complex transformations, where there are two predicates, and the second cannot exist without the first but can have a different subject (e.g. X knows/finds out/learns that Y has done something). Other instances for complex transformations, besides those of knowledge, are transformations of appearance, description, supposition, and attitude. It seems that the distinction Tzvetan Todorov draws between simple and complex transformations is a distinction between two types of modalities and the real difference between them is not only, as he claims, that in the first case there is only one predicate, while in the second case there are two, but rather that in the second case, the case of complex transformations, a subjectivity of a sort is presupposed. And one can argue that it is this subjectivity that allowed the introduction of the term 'point of view' in the field of narratology. It might seem, therefore, that there is a point of view only where we are dealing with complex transformations (appearances, knowledge, attitude, etc.). The point of view of a character is introduced, we might be led to believe, only if the characters not only act, or are able to act, or have to act, but also see, hear, think, know, learn, and have feelings with regard to the acts and states of affairs.

\section{Point of view, subjectivity, and modality}

It must be stated at this point that there are still various confusions and difficulties related to the use of the notion of 'point of view.' As Genette has correctly pointed out, from Percy Lubbock's The Craft of Fiction through Brooks and Warren's Understanding Fiction and J. Pouillon's Temps et Roman to the theories of F. K. Stanzel and Norman Friedman, there has been a theoretical overlapping of the problem of point of view and the problem of the narrator. ${ }^{13}$ Even Stanzel's elaborate distinction of the 'auctorial narrative situation,' the 'ego narrative situation,' and the 'personal narrative situation,' which makes it possible to not confuse the question of perspective, inner or exterior (relative to the auctorial narrative situation), with the question as to who is speaking (relative to the personal situation and the figure of the narrator), the final account ends up with a circular table that delineates transitions from

\footnotetext{
${ }^{12}$ Tzvetan Todorov, Poétique de la prose (Paris: Seuil, 1980), 117-132.

${ }^{13}$ Gérard Genette, Figures III (Paris: Seuil, 1972), 203-206.
} 
one narrative situation to another, as if the perspective and the narrating figure were at the same level. ${ }^{14}$ As is well known, Genette differentiates the two planes and terms 'voice' what is relevant to the narrator (and its relation to discourse and story) and 'focalisation' what is relevant to the point of view. ${ }^{15}$ According to him, the term 'focalisation' helps to avoid putting emphasis on the visual, which is still present in terms such as 'point of view,' 'vision,' or 'field. ${ }^{16}$ As to why we need to avoid visual metaphors, the answer would be that the narrative point of view concerns not only the vision but all types of perception, together with knowledge, cognition, and attitude; in short, all of the aspects that Tzvetan Todorov lists as introducing complex transformations. It is clear that 'point of view' should not be reduced to visuality, but is to include all perceptual and mental activities. Yet is this sufficient for a definition of 'point of view'? I will have to return to this question.

But first I will go back to the distinction between simple and complex transformation, both of which can be seen as forms of modalisation. There are several aspects to be noticed that Tzvetan Todorov does not mention. First, as I pointed out, all complex transformations presuppose a certain subjectivity. The one who is perceiving, thinking, feeling, etc. is by that very fact endowed with subjectivity. Even if the perception or the cognitive activity is supposedly that of an inanimate object (such as talking stations, puddles, dots, etc., in Donald Bisset's stories for children), it gives the object a form of mentality or a psychological dimension; it animates it. The act of ascribing a point of view to an inanimate object results in personification. But is the point of view limited to Todorov's complex transformations? The question can be reformulated in the following terms: Is the subjectivity that creates the possibility for a point of view in a narratological sense limited to the modalities of perception, emotion, and cognition?

In order to address these questions and to clarify the relationship between modality and point of view, I will turn to the narrative theory of Christo Todorov who, together with Krassimir Mantchev and others, developed the linguistic theory of Gustave Guillaume and its applicability to general semiotics and literary studies. ${ }^{17}$

Gustave Guillaume saw language as intrinsically linked to thinking and accused the kind of linguistics that "has avoided, as much as possible, to address the problems of morphology, from the 'inside,' from the side of thought." 18 What is characteristic of Guillaume's approach is that the mental activity

\footnotetext{
${ }^{14}$ See Franz Stanzel, Theorie des Erzählens (Göttingen: Vandenhoeck \& Ruprecht, 1979).

${ }^{15}$ See Genette, Figures III.

${ }^{16}$ Ibid., 206.

${ }^{17}$ More generally on the Bulgarian Guillaumist school, see the issue of Langage, no. 165 (2007), dedicated to "L'École guillaumienne de Bulgarie."

${ }^{18}$ Gustave Guillaume, Temps et verbe (Paris: Libraire honoré Champion, 1929), 6.
} 
underlying the emergence of grammatical categories, linguistic distinctions, etc. is not something that happens once and for all, so that the traces of their genesis disappear from the language. Close in a sense to Bergson, the French linguist insisted that the genesis of language forms a part of language, thus envisioning the language as a constant becoming that inscribes in itself traces of its becoming. In the words of Christo Todorov, "For Guillaume, the language draws its structure from the very process of its construction." ${ }^{19}$ In his major work Time and Verb, Guillaume demonstrated how the development of the temporal system of French verbs (which he called 'chronogenesis') has inscribed the moments of the process (called 'chronotheses') not only in the tenses of the verb but also in the infinitive and in the subjunctive mode. The chronogenesis is related to a transition from the virtual to the actual and produces 'time-images. ${ }^{20}$ More generally, Guillaume termed the linguistic articulations of the mental processes 'ideogenesis. ${ }^{, 21}$ Krassimir Mantchev and Christo Todorov particularly stressed the gradual differentiation of subject and object (in a rather philosophical sense, and not in the linguistic sense) in the process of ideogenesis. ${ }^{22}$ Mantchev called this process the 'progressive discrimination' of subject and object. According to this theory, in progressive discrimination there are "three stable positions of the basic operation, which correspond to the verbs to be [être], to have [avoir] and to do/to make [faire]." ${ }^{23}$ The gradual differentiation takes place in the transition from one of these stable positions to another; thus there are two instable positions of transition, res between to be and to have and between to have and to do. The first instable position is occupied by the modal verbs to be able (pouvoir), to want (vouloir), and to have to (devoir) - in that order. The second unstable position, i.e. the one between to have and to do, is occupied by verbs for perception and intellection. These verbs are called 'transmodal.' The whole scheme could be depicted in the following way:

$$
\begin{aligned}
& \text { 'to be' --o be able,' 'to want,' } \\
& \text { 'to have to' } \\
& \text { 'to foel,' 'to hear,' 'to see,' }
\end{aligned}
$$

${ }^{19}$ Christo Todorov, "Fondements linguistiques des études stylistiques," Études d'histoire de la littérature française (18-20 s.) (Sofia: Presses Universitaires "St. Kliment Ohridski," 1985), 62.

${ }^{20}$ And, of course, Deleuze's famous concept comes from Guillaume. It seems that despite Deleuze's influence, Guillaume remains not very well known to this very day.

${ }^{21}$ See Guillaume, Langage et science du langage (Paris: Librairie A.-G. Nizet, 1973); Krassimir Mantchev, Christo Todorov, "Eléments d'idéogénie," Annuaire de l'Université de Sofia, LXIV (1971); Krassimir Mantchev, "Approche de l'idéogenèse," in Langage et psychomécanique du langage, ed. André Joly, Walter H. Hirtle (Lille: Presses Universitaires de Lille, 1980), 62-74.

${ }^{22}$ See Mantchev, "Hiérarchie sémantique des verbes française contemporains," Cahiers de lexicologie, no. 10 (1967); Ch. Todorov, "La hiérarchie des liens dans le récit," Semiotica, no. 2 (1971),121-139.

${ }^{23} \mathrm{Ch}$. Todorov, "Fondements linguistiques des études stylistiques," 64. 
One will easily notice that the first two stable positions are occupied by auxiliary verbs, and all the other verbs can be combined in French with the infinitive form of other verbs. Already for Guillaume, "the verbs that become auxiliary are in no language just random verbs." ${ }^{24}$ According to Mantchev and Todorov, at the initial point the subject and the object are not differentiated. At the position of being ('to be'), the distinction between subject (ego) and object (thing) has not yet taken place. Gradually, with the transition from ability to obligation or duty, this distinction is operated. At the same time, according to the law of non-recurrence as formulated by Guillaume, every successive step does not efface but preserves the preceding one. ${ }^{25}$ Every stable position produces a new class of objects, and, consequently, a new part of speech. ${ }^{26}$ This becoming of language is operated again and again because the construction of the structure is a part of the structure.

In his works, Christo Todorov further developed this theory by applying it to the study of narrative. For him, modal verbs form a chronological axis and are hierarchically ordered in a manner that leads to an increasing force of actualisation: "the force of actualization of the modal verbs increases from pouvoir to devoir: pouvoir leaves to the infinitive almost all of its potential character (weak actualization); vouloir leaves but one part of its virtual possibilities (medium actualization); devoir translates most strongly the actualization that is compatible with the potential mode of the infinitive. It is this very force of actualization of the modal verbs, which is manifested in the organization of the narrative discourse." ${ }^{27}$ In other words, where there are only possibilities there is nothing determinate that would lead to a particular actualisation of a chain of acts and events. In the case of desire, there is something that can lead to the development of the story in a particular direction, and that direction is further determined if there is an obligation. The force of actualisation is also related to what Todorov calls 'integrity' of the story. The three modal verbs form degrees of the story's coherence and function as 'integrators.' The pure possibility in this respect differs little from the simply given state of affairs. ${ }^{28}$

${ }^{24}$ Guillaume, Langage et science du langage, 73.

${ }^{25} \mathrm{Ch}$. Todorov, "Analyse stylistique de deux récits de Marcel Aymé," Études d'histoire de la littérature française (18-20 s.) (Sofia: Presses Universitaires "St. Kliment Ohridski”, 1985), 73-74.

${ }^{26} \mathrm{Ch}$. Todorov, "Valeur esthétique et normalité linguistique du texte littéraire," Études d'histoire de la littérature française (18-20 s.) (Sofia: Presses Universitaires "St. Kliment Ohridski," 1985), 147.

${ }^{27} \mathrm{Ch}$. Todorov, "La hiérarchie des liens dans le récit," Semiotica, 130. It is noteworthy that there is no such hierarchy and no chronological axis in the case of transmodal verbs. With them there seems to be an established relationship of the subject to the object, which is no longer that of the passive possession of avoir, and yet it is not the full activity of faire either. Still, there seems to be no special order of perception, emotion, and cognition.

${ }^{28}$ Todorov points to cases of functional equivalence between being and ability; thus 'being rich' equals 'the ability to buy.' (Ch. Todorov, "Valeur esthétique et normalité linguistique du texte littéraire," 165.) 
Nothing follows necessarily from a possibility or an ability; therefore, in this case Todorov speaks of weak coherence and an open intrigue where the different episodes are relatively autonomous. ${ }^{29}$ Desire introduces intentionality and finality, and finality only grows stronger with obligation and duty, where coherence is the strongest.

Of course, as in Greimas, a combination of modalities is possible and the history of literature offers various examples. There can be a conflict stemming from the clash of desire and obligation, or of two desires, or of two incompatible obligations, etc. When such a conflict occurs in one and the same subject, it leads to interiorisation and psychologisation of the character. The conflict between desire and possibility leads in a different direction, as in the case of La Fontaine's fable about the fox and the raven, where first the fox wants the cheese that the raven has but cannot get it; because of this initial situation, in the second step the fox wants to deceive the raven, and so on.

Furthermore, Todorov points out that the French language makes it possible to discriminate between an objective and a subjective variant of the third modality, res falloir and devoir. The objective variant, where something must be done, has different manifestations depending on whether it is thematised or not, ranging in this way from fate and the unavoidable, to historical necessity or social norms and constraints. ${ }^{30}$ Later, Krassimir Mantchev demonstrated that all modal and transmodal categories have subjective and objective counterparts. ${ }^{31}$ Thus the subjective ability has its counterpart in the objective possibility, the subjective desire has its counterpart in some objective deficiency or lack, etc. This does not contradict the idea of progressive discrimination of subject and object because, from the perspective of their theory, it could be stated that the discrimination between ability and possibility is weaker than that between falloir and devoir.

Christo Todorov's Guillaumist approach to modality is both close to and different than Greimas'. Both theories make it obvious that the narrative logic is multimodal. In both theories the modalities can be linked syntagmatically in the course of the story but can also be synchronically combined, which leads to new dispositions of forces and new conflicts. Yet with Todorov not only knowing (savoir) is excluded from the group of the other three modalities, but these are in a hierarchical order determining the integrity of the story and thus its very logic. To Greimas' couple of being and doing, a third term is added and that is having. The modalisations in Todorov are not, as Greimas claims, primarily modalisations of being and doing but transitions from being through having to doing alongside the progressive discrimination of subject and object.

${ }^{29}$ Ibid.

${ }^{30}$ Ibid., 194-201.

${ }^{31}$ Mantchev, Sémiotique et narratologie (Sofia: Presses Universitaires "St. Kliment Ohridski," 1998), 120-122. 
This makes it possible to point to the precise position of each category following the modal/transmodal distinction.

That such a distinction is necessary was already indicated with reference to the way Tzvetan Todorov differentiates simple and complex narrative transformations. Tzvetan Todorov's criterion was based on whether there is only one predicate or two. I pointed out that with complex transformations we have to deal with a certain subjectivity. Now, with Christo Todorov, one can be more precise. According to him, "the modal categories characterize the action, while the transmodal characterize the subject of the action." 32 It is for this reason that the "transmodal categories do not function as integrators." ${ }^{33}$ Implicitly following Aristotle, Christo Todorov claims that there can be a story without transmodal categories, but not without the modal ones. In the case when there no longer seem to be modal categories, and only transmodal ones, as in some of Alain Robbe-Grillet's novels, the story can no longer maintain its coherence and its integrity falls apart.

At this point we can return to the question of the point of view. It seems at first glance that the notion of 'point of view' should be related to the transmodal categories. Undoubtedly, perception, emotion, and intellection have to do with the point of view. This is so obvious that for the large part scholars have avoided asking whether that is all there is to it. Above I posed the question if the subjectivity that creates the possibility for a point of view in a narratological sense is limited to the modalities of perception, emotion, and cognition, and here I will return to this question. For even though the transmodal categories characterise the subject of action, the progressive discrimination of subject and object takes place already at the level of the modal categories. There is subjectivity in the notions of ability, desire, and obligation. Is this subjectivity sufficient in order to speak of point of view also at the level of modality (and not only at that of transmodality)?

Christo Todorov's answer to this question is positive. He conceives the point of view as a "linguistic notion," which is not to be conceived in a psychological, moral, social, or other manner, for "it is only the form of the Subject that is important"; $; 4$ "However, if one can find in the text notions modal and transmodal (of perception and cognition) playing the role of form-matter, then it is inevitable that these verbs create at the same time the diffuse and implicit image of the form of the Subject that they construct in themselves [...]. This diffuse image of the Subject is the category of the point of view." ${ }^{35}$ According to him,

\footnotetext{
${ }^{32} \mathrm{Ch}$. Todorov, "Valeur esthétique et normalité linguistique du texte littéraire," 171-172.

${ }^{33}$ It should be added: at the semantic level of narrative logic.

${ }^{34}$ Ch. Todorov, "Analyse stylistique de deux récits de Marcel Aymé," 75.

${ }^{35} \mathrm{Ch}$. Todorov, "Problèmes psycholinguistiques du texte narratif," Études d'histoire de la litté-
} rature française (18-20 s.) (Sofia: Presses Universitaires "St. Kliment Ohridski," 1985), 123-124. 
there are two types of point of view depending on whether they are related to the modal categories or to the transmodal ones. The modal point of view produces three subject images. ${ }^{36}$ The first one, produced by the category of ability, is rather amorphous, for there the subject and the object are not clearly distinguished and the potentiality could just as well be in an inanimate object as in an animate subject. The desire (together with the notions of intention, interest, etc.) produces the image of a particular subject. The obligation produces the image of an impersonal, generalised, subject, and this subject is usually translated at the level of discourse by moral categories such as 'good' and 'bad.' The transmodal point of view is divided by Todorov into the perceptional and cognitive point of view, and these two are further divided into subcategories based on the dominance of the subjective or the objective part.

This understanding of the point of view seems very productive. Yet if the modal and transmodal categories produce an image of the subject, why call this image the point of view? Christo Todorov's arguments here pose a particular problem. The idea for a subject image supposes that if there is a point of view, it would be rather turned toward the image of the subject, and not the subject's own point of view. How should one think of the point of view? How should one conceive it if one wants to avoid a misleading visual metaphor but also the psychologisation of the notion of subject on which it is based? The point of view is associated with a specific position of the subject. But it is not the position alone that defines it. For if we have a stone in a sandbox, its position can be very precise and we still will not be dealing with a point of view. I believe that what is defining for the point of view is its directedness. What is needed in order to have a point of view is an orientation, a direction. To put it another way, the point of view presupposes vectorisation. The orientation, the direction, are not to be confused with movement, for there can be a direction without movement.

The constant becoming of subject and object, their ideogenesis at the level of the story, produces precisely directedness at two different levels, i.e. at the level of the modal categories and at the level of the transmodal ones. Therefore, I would argue that the point of view is not to be thought of only as related to perception, emotion, and intellection, to what Tzvetan Todorov calls complex transformations, but also as related to the most basic narrative modalities, such as desire and obligation. These modalities orient the subject in the very way they produce it and direct it in a specific way towards an object.

Progressive discrimination is associated with the production of new objects, and thus the very form of directedness changes from the modal to the transmodal level. The model categories characterise the action and therefore they

\footnotetext{
${ }^{36}$ Ibid., 124.
} 
orient the chain of events of the story, thus building its logic. The transmodel categories characterise the subject of the action, and thus orient its relation to what is happening. Only in an indirect way, as modified by the other modalities (e.g., the desire to see, the need to know, the possibility to feel), can they participate in the construction of the logic of the story. Meanwhile, it will have become obvious that at the level of the modal categories the point of view should not be thought of as a constant. It is gradually produced from the amorphous possibilities of 'ability' to the particularity of the desire to the general norms, interiorised or not, of the obligation. Therefore, it seems only appropriate to think of the point of view at the modal level also in gradual terms. In other words, there can be stories where the modal point of view is "weaker," being based on possibilities, as in some adventure novels, where the character is passive while different events befall him or her; and other stories where the modal point of view is "stronger," as in the case of the French classicist tragedies, which are often based on the conflict between duty and desire. The case of the third modality should be studied separately, because with the impersonal, general subject it introduces - it implies - in the character or beyond him or her a different perspective, somewhat exterior, namely the point of view of fate, history, society, etc. And here again it might be the case that when non-thematised, this modal point of view simply vanishes. On the other hand, it is here that one can study the most explicit instances of the way social norms and conceptions become immanent narrative categories.

\section{Directions and transitions}

If there are two levels and one can distinguish the modal point of view from the transmodal one, then what are the possible relationships between these two levels?

It was already pointed out that the modalisations of the transmodal categories allow for the transmodal categories to participate in the very construction of narrative logic; thus, for example, in the case of crime fiction the cognitive process (say a detective investigating a crime) is driven by a need/duty/obligation/ desire to understand what happened. At the same time, here the object of cognition (of the investigation) is not a usual object but another story with its own modalities (why the perpetrator wanted to or had to perform the crime, etc.). This peculiarity of crime fiction therefore makes evident not only the modalisation of transmodalities but also the transmodalisation of modalities (to see the desire, to understand the need, etc.). ${ }^{37}$

${ }^{37}$ On the question of transmodal transitions, see Boyan Manchev, Nevuobrazimoto [The Unimaginable] (Sofia: New Bulgarian University, 2003). 
The fact of this entanglement of modalities and transmodalities might lead one to the idea that the difference between the two levels is delusive. Yet it should be noted that in the case of transmodal categories one moves from the story to the relationship between the story and the discourse. It is not by chance that Genette positions focalisation in the section of mood that describes "the regulation of narrative information," 38 in other words, the access to the story given by the discourse. Pertaining to the subject of the action, transmodality has an in-between position, i.e. it consists of actions granting access to other actions, but this is a specific, "subjective" access.

The consequence of this in-between-ness of transmodality can make the modal point of view more perceptible, but it can obscure it just as well. In Christo Todorov's terms, the transmodal "subject image" can cover and veil the modal one. The opposite, however, is not true, for according to Guillaume's law of non-recurrence, the modal categories are inherent to the transmodal, i.e. they come first and can exist without the transmodal categories, but for this very reason if they come to "obscure" the transmodal level, this would mean that the transmodal level is no longer in the story, not just hidden. On the other hand, even when the transmodal point of view veils the modal one, the modality does not disappear, or at least not without taking the very coherence of the story away.

So far I have described the point of view as a form of directedness related to the discrimination of subject and object. The transitions from one modality to another at a given level as well as the possible entanglement of the modal and the transmodal level indicate that this directedness, this orientation, does not concern only the subject-object relation. Narrative modalities make it clear that the directedness of the point of view is at least double. Besides the subject-object complex there is an inter-modal orientation; to put it differently, the modalities always point to other modalities, and sometimes the transmodalities point to other transmodalities, the modalities to the transmodalities, and the transmodalities to the modalities. If the main protagonist wants something (an object in the most general sense) but cannot have it, he or she must find a way to get it, which can be translated as a transition from the desire of an object to the desire for an ability. The receiving of the ability can lead to other desires, etc. Thus the double direction of the (trans-)modal point of view is, on the one hand, the direction of a subject to an object and, on the other, the direction from one modality to another. If this is indeed the case, then it must be stated that in any narrative there are multiple points of view; some of them are weaker, others are stronger. They can interact, veil each other, contradict, collaborate, and consolidate, and so on. But they can also appear and disappear.

\footnotetext{
${ }^{38}$ Genette, Figures III, 184.
} 
The narrative points of view are ineluctably modal or transmodal, and that is why they are in constant transformation, moving from the virtual to the actual and from the actual to the virtual, i.e. from the particular to the general and back.

\section{Modelling narrative modalities}

At the end, instead of a conclusion I would like to point to some of the problems and deficiencies of the Guillaumist narratology, and to return very shortly to the model theory I mentioned at the beginning.

A theory like the one developed by Christo Todorov, which I took up in this paper in order to study the problem of the relationship between narrative modalities and point of view, can be very productive. It is not, however, without its risks. The first and probably most obvious is the risk of wanting to naturalise the theory, i.e. to accept the theory not as a construct built upon language models $^{39}$ but as a direct description of how things are. To naturalise the theory would be to take the model for the "thing itself."

Furthermore, even if one accepts the distinction between stable and unstable positions in the ideogenesis, and also the distinction between modal and transmodal categories, it is doubtful whether these particular categories (e.g., pouvoir, vouloir, devoir) are universal. Christo Todorov's model is convincing because it employs often used French modal verbs, but it would be enough to look again at other theories of modality, or at the simple narrative transformations listed by Tzvetan Todorov, to see other options. Tzvetan Todorov, for his part, enumerates six simple transformations that offer a completely different picture. ${ }^{40}$ The modalities vary even more from one language to another. Thus, in English

\footnotetext{
${ }^{39}$ And it should probably be mentioned that Guillaume's linguistics was rather critical of Saussure, arguing against the arbitrariness of the sign (see Maurice Toussant, Contre l'arbitraire du signe (Paris: Didier Erudition, 1983)), and thus against a large part of the structuralist presuppositions, thus offering a different language model. In relation to literary theory, the Bulgarian Guillaumist school fought against the structuralist dogma that literature is a second order system, a connotative system based upon the first order system of natural language. For Christo Todorov, linguistic ideogenesis is directly observable in literature, it is being operated in and as literature. Being no second language, literature is not defined by extralinguistic criteria but solely by the language whose becoming it is; (see his critique of Barthes in Ch. Todorov, "Kritika na literaturovedskite vuzgledi na Roland Barthes" ["A Critique of the literary-theoretical conceptions of Roland Barthes"], Literaturna misul, no. 2 (1973), 10-28). As thought-provoking as such an idea is, it led Todorov to the universalisation of linguistic categories, which, after all, come from and are pertinent in French.

${ }^{40}$ These are transformations of mode (including all of the alethic modalities plus pouvoir and devoir), of intention, of result, of manner, of aspect, and of status; (see Tz. Todorov, Poétique de la prose, 125-126). The incongruences in the manner that Tzvetan Todorov builds this list will not be discussed here.
} 
the third modal category would lead to a differentiation that would be rather incompatible with that of falloir and devoir. One will have to deal with 'must,' 'ought,' 'should,' and 'have to.' The German language presents yet a different picture, not to speak of non-Indo-European languages. The modal and transmodal categories are themselves socially and culturally determined and may greatly vary from culture to culture. This fact does not devaluate the Guillaumist theory, but it should make us careful in its application. For it might be stated that these categories show not only the psycholinguistic but also the sociolinguistic aspects of the ideogenesis. Social and cultural norms and conceptions define the deontic modalities but also the volitive ones, the alethic ones, etc. It is in this way that the logic of the story, or what I called in the first part of the paper the 'narrative potentiality,' is defined in its core by social conventions and cultural attitudes. And for these very reasons narrative potentiality is modelled in the works in various manners and has different manifestations.

Model theory has to tackle the following question: How does one take into account narrative modalities? It can be stated that the social conventions function as a matrix for the model that the story itself constructs. At the same time, however, they function in a mediated way also as a modelling agency for this construction. ${ }^{41}$ On the one hand, this means that when we are building a model of the narrative models of the texts under study (and with literature we are always building models of models), we have to take into account the social, historical, and cultural contexts and conventions. And in this sense narratology is inseparable from disciplines such as sociology or cultural studies. On the other hand, however, we should not try to explain away the model of the narrative text that we are building a theoretical model on by purely external means. Not only are the imposed conventions themselves in a constant becoming, constant transformation, as Guillaume and his followers showed convincingly, and therefore can be modified in their turn by the works (Kafka's oeuvre is a good place to look in order to see how this modification is operated), but also, and more importantly, if modal and transmodal categories are introduced in the story then the story itself will indicate them and in this way they will be inducible from the story. Society, history, and culture may function as a matrix or a modelling agency, but in any case they will be inscribed in the story as pertaining to its logic and therefore may be reconstructed by a model which takes into account the work's own characteristics. A good theoretical model should be built with

${ }^{41}$ Here I use the terms 'matrix' and 'model agency' in the sense of Bernd Mahr (with regard to the general theory of models) and Robert Matthias Erdbeer (with regard to the literary theory of models); see Mahr, "Modelle und ihre Befragbarkeit. Grundlage einer allgemeinen Modelltheorie," Erwägen Wissen Ethik, no. 26 (2015), 329-342; Mahr, "On the Epistemology of Models," in Rethinking Epistemology, ed. Günter Abel, James Conant (Berlin, New York: Walter de Gruyter, 2011), 301-352; Erdbeer, "Poetik der Modelle." 
the use of the means of the literary model as formal indications of its knots of potentialities, following, as it were, the works' own instructions.

From this perspective, the becoming and dynamics of multiple points of view at the level of the story ${ }^{42}$ may offer an exceptional guiding light.

\title{
Su m m a ry
}

In this paper I will envisage the relationship between narrative modalities and point of view with the help of the narratological theory of Christo Todorov, who is a representative of the Bulgarian Guillaumist school. First, I will point to the multimodality of narrative modal logic with its combination of different types of modal categories (alethic, deontic, volitive, etc.). Then I will introduce Christo Todorov's distinction between modal and transmodal categories, according to which modality (ability, desire, obligation) is what characterises the actions and transmodality (perception, emotion, intellection) is what characterises the subject of action. Along with Todorov I will claim that there are both modal and transmodal points of view, but unlike him I will define the point of view based not on the subject-image but on the directedness it introduces. My point will be that there is a double direction of the point of view: on the one hand, the direction of the subject to the object, and, on the other, the direction from one modality to another. This double direction, I will argue, is at the very basis of narrative logic, or of what I would call the 'narrative potentiality.'

\section{PUNKT WIDZENIA A MODALNOŚCI NARRACYJNE}

\author{
Streszczenie
}

Z pomocą teorii narratologicznej Christo Todorova, przedstawiciela bułgarskiej Szkoły Guillaumistów, nakreślam w artykule relację między modalnościami narracyjnymi a punktem widzenia. Po pierwsze, zwracam się ku wielomodalności narracyjnej logiki modalnej z jej kombinacją różnych typów kategorii modalnych (aletyczna, deontyczna, wolicjonalna itd.) Następnie za Christo Todorovem wprowadzam rozróżnienie na kategorie modalne i transmodalne, zgodnie z którym modalność (zdolność, pragnienie, przymus) charakteryzuje działania, transmodalność zaś (percepcje, emocja, intelekt) charakteryzuje podmiot działań. Za Todorovem twierdzę również, że istnieją także modalne i transmodalne punkty widzenia, jednak w przeciwieństwie do badacza definiuję punkt widzenia, odwołując się nie do obrazu podmiotowego, lecz do ukierunkowania, które on wprowadza. Stawiam tezę, że w punkcie widzenia można wyróżnić dwojakie ukierunkowanie: z jednej strony, ukierunkowanie podmiotu na przedmiot; z drugiej zaś, ukierunkowanie jednej modalności na drugą. To podwójne ukierunkowanie stanowi rdzeń logiki narracyjnej czy raczej czegoś, co bym nazwał „narracyjną potencjalnością”.

${ }^{42}$ In the present paper, for the sake of brevity, I left aside problems posed by both the author's and the reader's viewpoint. 